\title{
Famílias políticas no Líbano e no Brasil, a possibilidade da perspectiva comparativa
}

\author{
Alessandro Cavassin Alves ${ }^{1}$
}

O artigo de Ward Vloeberghs (Dinâmicas dinásticas no Líbano: transmitir o poder político em $f_{\left.a m i ́ l i a^{2}\right)}$ analisa o "fenômeno dinástico na política", isto é, quando um "número considerável de famílias" transmitem cargos eletivos ou administrativos públicos para seus próprios membros; e isso na República do Líbano, sob o contexto de uma democracia regular e competitiva. Para tanto, o autor, situa o leitor no contexto histórico, religioso e político libanês (e as características próprias da democracia libanesa sob esse amplo contexto), demonstrando, também, a centralidade da instituição familiar nesta estrutura social, que, portanto, reflete na organização política da nação.

Neste sentido, este artigo possibilita comparar o mesmo fenômeno político com o caso brasileiro, tão visível e intenso, neste país. Por exemplo, reportagens demonstram a importância da família na carreira política brasileira: "Herdeiros de políticos ocupam metade da Câmara", por Étore Medeiros (Congresso em Foco, 03/02/2016)3; “Congresso: um negócio de família; seis em cada dez parlamentares têm parentes na política", por Edson Sardinha (Congresso em Foco, 01/08/2017) ${ }^{4}$. Nesta mesma perspectiva comparativa, destaca-se a intensa produção acadêmica realizada pelo NEP (Núcleo de Estudos Paranaenses, da Universidade Federal do Paraná), em seus mapeamentos das famílias políticas brasileiras, através da sua revista e dos respectivos livros 5 .

Assim como faz Vloeberghs, analisando o caso da família sunita Salam, no poder desde o século XIX, ou de famílias mais recentes, como a família sunita dos Hariri, desde a década de 1980, no Líbano, o

\footnotetext{
${ }^{1}$ Graduado em Ciências Sociais pela Universidade Federal do Paraná. Mestrado e Doutorado em Sociologia pela UFPR. Atua como docente compondo o Quadro Próprio do Magistério no Governo do Estado do Paraná e na Faculdade São Basílio Magno e UNIANDRADE. Endereço eletrônico: alessandrocavassin@gmail.com
}

\footnotetext{
${ }^{2}$ Texto original «Dynamiques dynastiques au Liban: transmettre le pouvoir politique en famille», Critique internationale, vol. 73 , № 4, 2016, p. 71-93. Disponível em https://www.cairn.info/revue-critique-internationale-2016-4-page-71.htm. Acesso 25.outubro.2017.

3 Disponível em: http://congressoemfoco.uol.com.br/noticias/herdeiros-de-politicos-ocupam-metade-da-camara/ Acesso em 29/12/2017.

${ }^{4}$ Disponível em: http://congressoemfoco.uol.com.br/noticias/congresso-um-negocio-de-familia-seis-em-cada-dez-parlamentarestem-parentes-na-politica/. Acesso em 29/12/2017.

${ }^{5}$ Revista NEP - Núcleo de Estudos Paranaenses da UFPR. Disponível em: http://revistas.ufpr.br/nep. Acesso em 29/12/2017. VANALI, Ana Christina \& OLIVEIRA, Ricardo Costa de. (Org.). (2017). Instituições e poder político. Curitiba: Editora Prisma. OLIVEIRA, Ricardo Costa de. (Org.). (2016). Nepotismo, parentesco e mulheres. Curitiba: RM Editores.

OLIVEIRA, Ricardo Costa de. (Org.). (2015). Estado, classe dominante e parentesco no Paraná. Blumenau: Nova Letra.
} 
NEP, sob a coordenação do Prof. Dr. Ricardo Costa de Oliveira, analisa a estrutura e o ethos de famílias políticas "a partir de diversos casos empíricos", no Brasil. Enfim, há uma semelhança de ação para a perpetuação no poder, utilizada tanto por políticos libaneses, como por brasileiros, mesmo sendo países com culturas díspares.

Mas, o que o Líbano e o Brasil têm a mais em comum em relação a famílias políticas?

Chama a atenção, para o caso brasileiro, é de que muitos descendentes de imigrantes libaneses, que vieram para o Brasil a partir da década de 1880, encontraram, portanto, aqui, um ambiente político familiar muito semelhante ao que acontece em seu país de origem (basta observar a importância da família na organização histórica e política libanesa, descrita por Vloeberghs, assim como é no Brasil, cada qual, entretanto, com suas características e histórias específicas).

E, destacam-se, assim, inúmeros políticos de descendência libanesa hoje no Brasil e que acabam seguindo o mesmo padrão, (libanês ou brasileiro?), de herdar ou repassar seus cargos públicos a seus familiares. Veja o caso, no Brasil, da família Richa; família Khoury; família Skaf; família Gebran; família Kassab; entre tantas outras.

Enfim, o artigo de Ward Vloeberhs, sobre "dinâmicas dinásticas no Líbano", remete a uma lógica familiar e política semelhante a do Brasil. E mais, sugere pesquisas amplas sobre políticos brasileiros, que são descendentes de libaneses, e que seguem o mesmo padrão político familiar. Eis uma pesquisa a se realizar. 